\title{
Malignant Type B1 Thymoma
}

National Cancer Institute

\section{Source}

National Cancer Institute. Malignant Type B1 Thymoma. NCI Thesaurus. Code C7996.

A type B1 thymoma which is characterized by an aggressive clinical course (capsular invasion, infiltration of the surrounding tissues) and can metastasize. 